\title{
FAKTOR-FAKTOR YANG MEMPENGARUHI STRUKTUR MODAL PERUSAHAAN
}

\author{
Dede Yusuf ${ }^{1}$, Irdha Yusra ${ }^{2)}$ \\ ${ }^{1,2)}$ Sekolah Tinggi Ilmu Ekonomi KBP \\ Email $^{1)}$ : dedey1180@ gmail.com \\ Email $^{2)}$ irdhayusra@akbpstie.ac.id
}

\begin{abstract}
The company is a group that has the aim to get the maximum benefit possible by utilizing existing resources as optimally as possible. Companies in general will not be able to finance all of their operational activities by using their own capital, because of limited funds from the leadership of the company. hence the company tries to utilize the resources they have such as tangibility and the company's growth rate to obtain additional capital. This study aims to determine how much tangibility and growth rates can influence companies in setting capital structures. The population in this study are all companies listed on the Indonesia Stock Exchange during the end of the 2013-2017 period. In this study using purposive sampling technique in sampling and obtained a sample of 19 companies with 95 observations. Panel data regression analysis in this study uses the help of the E-Views 8 application and tests CEM, FEM and REM to determine the best model. The test results state that tangibility has a positive and significant effect on company leverage, while the growth rate does not significantly influence company leverage.
\end{abstract}

Keywords: Tangibility, Growth Opportunity, Leverage

\section{PENDAHULUAN}

Untuk mencapai tujuan utama perusahaan di tengah persaingan di dunia bisnis yang semakin ketat yaitu mendapat keuntungan yang se optimal mungkin, perusahaan dituntut untuk dapat mengungguli kompetitornya. Oleh sebab itu guna meraih tujuan tersebut maka diperlukan pengambilan keputusan pendanaan yang tepat dari manajemen perusahaan. Penggunaan utang terdapat keuntungan dan kerugian. Keuntungan dari penggunaan utang adalah mengurangi pajak yang dibayarkan perusahaan karena ada bunga yang harus dibayarkan, sedangkan kelemahan daripada utang antara lain kreditur akan menaikan tingkat suku bunga karena efek dari penggunaan utang yang semakin besar (Indrajaya, 2011). Dengan situasi dimana perusahaan terlalu banyak memiliki utang, perusahaan akan sulit berkembang dan membuat investor berpikir kembali ketika menanamkan modalnya.

Tabel 1

Data Leverage Perusahaan Sampel yang dipilih secara Random

\begin{tabular}{llllllll}
\hline NO & EMITEN & KODE & 2013 & 2014 & 2015 & 2016 & 2017 \\
\hline
\end{tabular}




\begin{tabular}{|c|c|c|c|c|c|c|c|}
\hline 1 & $\begin{array}{l}\text { Fast Food Indonesia, } \\
\text { Tbk }\end{array}$ & FAST & 0.84 & 0.81 & 1.07 & 1.11 & 1.09 \\
\hline 2 & Adaro Energy, Tbk & ADRO & 1.11 & 0.97 & 0.78 & 0.72 & 0.67 \\
\hline 3 & $\begin{array}{l}\text { Semen Indonesia } \\
\text { (Persero), Tbk }\end{array}$ & SMGR & 0.41 & 0.37 & 0.39 & 0.45 & 0.61 \\
\hline 4 & Mayora Indah, Tbk & MYOR & 1.47 & 1.51 & 1.18 & 1.06 & 1.02 \\
\hline 5 & $\begin{array}{l}\text { Adhi Karya (Persero), } \\
\text { Tbk }\end{array}$ & ADHI & 5.28 & 4.97 & 2.25 & 2.69 & 3.83 \\
\hline
\end{tabular}

Sumber: $\underline{w w w . i d x . c o . i d}$

Berdasarkan Tabel 1 diatas, dari 19 Perusahaan yang dijadikan sampel, dipilih 5 Perusahaan secara acak yang mempunyai data Debt to Equity Ratio yang mengalami fluktuasi, hal ini disebabkan karena Tangibility yang diukur dengan FATA dan Tingkat Pertumbuhan yang diukur dengan Asset Growth juga mengalami fluktuasi tiap tahunnya. Kesalahan dalam menentukan struktur modal akan berpengaruh bagi kelangsungan perusahaan, jika perusahaan terlalu banyak menggunakan utang beban perusahaan pun akan semakin besar, dimana kondisi demikian akan menaikan resiko keuangan perusahaan jika perusahaan tidak mampu membayar kewajibannya.

Keputusan pendanaan eksternal suatu perusahaan sangat ditentukan oleh struktur asset atau Tangibility perusahaan tersebut, karena aktiva tetap yang dimiliki oleh perusahaan dapat dijadikan jaminan atau collateral bagi pihak kreditur dalam mengajukan pinjaman (Kadek, Merta, \& Badjra, 2012). Dalam membuat keputusan pendanaan, manajemen juga memperhatikan tingkat pertumbuhan perusahaan. Perusahaan dengan tingkat pertumbuhan yang tinggi cenderung akan menggunakan pendapatan sebagai sumber pendanaannya (Tommy \& Admaja, 2010) sehingga Leverage perusahaannya rendah.

Beberapa penelitian sebelumnya telah melakukan kajian secara empiris mengenai pengaruh tangibility dan tingkat pertumbuhan terhadap leverage perusahaan. Sutejo, (2015) menyatakan bahwa tangibility memiliki pengaruh positif dan signifikan terhadap Leverage, hal ini sesuai dengan trade off theory, yang menyatakan bahwa bentuk aset yang dimiliki perusahaan mempengaruhi struktur modalnya dan tingkat pertumbuhan memiliki pengaruh positif tidak signifikan terhadap leverage, hal ini sesuai dengan teori signaling, dimana perusahaan yang sedang tumbuh sangat banyak melakukan investasi dalam proyek-proyek yang berisiko untuk masa depan perusahaan, hal ini menyimpulkan jika tingkat perumbuhan naik maka menyebabkan kenaikan pula pada leverage.

Menurut Cahyani, (2017) dalam penelitiannya menyatakan semakin besar aset yang dimiliki oleh perusahaan, maka semakin besar pinjaman yang diperoleh oleh perusahaan atas jaminan yang diberikan kepada kreditur. Tommy \& Admaja, (2010) menemukan bahwa perusahaan dengan pertumbuhan tinggi 
menginginkan menikmati keuntungan dari pertumbuhan dan berinvestasi dari dana internal agar struktur modal rendah.

Mengingat banyaknya kajian empiris yang menyatakan bahwa terdapat pengaruh tangibility dan tingkat pertumbuhan terhadap leverage perusahan. Maka dari itu peneliti merasa tertantang untuk melakukan kajian secara mendalam, terutama untuk menjawab permasalahan tentang besar atau kecilnya pengaruh tangibility dan tingkat pertumbuhan terhadap leverage perusahaan yang terdaftar di BEI selama periode 2013-2017.

Menurut Tommy \& Admaja, (2010) dengan proksi leverage long-debt to asset juga menunjukan bahwa tangibility memiliki korelasi positif dan signifikan terhadap leverage, karena jaminan yang semakin tinggi akan membuat perusahaan meningkatkan utangnya. Karena berdasarkan trade off theory beban bunga hutang akan mengurangi pajak penghasilan dan memungkinkan perusahaan meningkatkan nilainya.

Perusahaan mampu memberikan jaminan utang apabila memiliki aktiva tetap yang besar. Maka dari itu ada korelasi yang baik antara tangibility dengan leverage perusahaan, dimana adanya saling keterkaitan antara tangibility dengan leverage perusahaan ketika perusahaan merencanakan mengajukan utang, karena jaminana yang diserakan pada saat pinjaman akan membuat bunga perusahaan untuk membayar bunga utang utang yang lebih kecil. Semakin besar tangibility assets yang dimiliki oleh perusahaan, maka semakin besar pinjaman yang dapat diperoleh oleh perusahaan atas jaminan yang diberikan kepada kreditur (Kadek et al., 2012).

Dari penjelasan di atas, maka dapat dibangun hipotesis pertama adalah sebagai berikut:

\section{H1: Tangibility berpengaruh positif dan signifikan terhadap Leverage}

Perusahaan yang semakin tinggi tingkat pertumbuhannya maka akan semakin tinggi pula asimetri informasi terjadi, sehingga dibandingkan menerbitkan saham baru, perusahaan akan menggunakan utang terlebih dahulu, Indrajaya, (2011). Semakin besar dana yang dibutuhkan mengindikasikan tingkat pertumbuhan perusahaan semakin tinggi dan akan membuka kesempatan perusahaan bertumbuh lebih tinggi.

Pecking order theory menyatakan perusahaan akan lebih menggunakan hutang untuk modal kerjanya, sebagai jaminan untuk kreditur, perusahaan akan menjaminkan aset tetapnya agar memperoleh hutang. Hal ini sesuai dengan penelitian yang dilakukan oleh (Cahyani, 2017) yang menyatakan perusahaan yang memiliki aset yang banyak akan lebih mudah dalam mendapatkan pendanaan eksternal karena aset tersebut dapat digunakan sebagai jaminan apabila perusahaan tidak dapat melunasi kewajibannya.

Dari penjelasan di atas, maka dapat dibangun hipotesis kedua adalah sebagai berikut: 


\section{H2: Tingkat Pertumbuhan berpengaruh positif dan signifikan terhadap Leverage}

Perusahaan yang sedang mengalami pertumbuhan cenderung akan berusahaan untuk mengembangkan usaha atau asetnya, karena dapat meningkatkan nilai perusahaan itu. Namun karena tingginya tingkat pertumbuhan maka akan tinggi pula penghasilan yang terkena pajak sedangkan perusahaan akan melakukan pengembangan usaha. Tentu hal tersebut akan menjadi masalah bagi manajemen perusahaan.

Trade off theory menyatakan bahwa tingkat penghasilan yang terkena pajak akan berkurang apabila ada beban bunga hutang yang harus dibayarkan perusahaan. Maka dari itu peneliti berasumsi bahwa perusahaan dengan tingkat pertumbuhan tertentu akan menggunakan hutang untuk membiayai modal kerjanya sehingga keuntungaan yang didapatkan pada periode sebelumnya dapat digunakan untuk mengembangkan usahanya.

Hal ini didukung oleh penelitian yang dilakukan (Indrajaya, 2011) yang menyatakan bahwa semakin tinggi tingkat pertumbuhan yang dialami perusahaan, maka semakin tinggi pula proporsi penggunaan hutang yang digunakan perusahaan.

\section{METODE PENELITIAN Data dan Sampel}

Penelitian ini dilakukan pada seluruh perusahaan yang terdaftar di Bursa Efek Indonesia. Dasar pemilihan obyek ini dilakukan karena pada penelitian ini menggunakan regresi data panel dalam pengujiannya dan untuk menambah manfaat akademis dari penelitian sebelumnya.

Jenis data yang digunakan pada penelitian ini adalah data kuantitatif. Data kuantitatif yang digunakan didapatkan dari laporan keuangan perusahaan yang menjadi sampel, adapun data yang digunakan yaitu debt to equity ratio, fixed asset, total asset dan tingkat pertumbuhan aset perusahaan selama akhir periode bulan Desember 2013 sampai dengan Desember 2017. Sedangkan observasi dokumentasi digunakan sebagai teknik pengumpulan data.

Populasi pada penelitian ini adalah semua perusahaan yang terdaftar di BEI selama periode 2013 sampai dengan 2017. Pada penelitian ini digunakan teknik purposive sampling dalam menseleksi sampel yang akan digunakan, yaitu pengambilan sampel berdasarkan kriteria atau penilaian tertentu. Adapun kriteria atau penilaian yang digunakan antara lain:

1. Perusahaan yang terdaftar di Bursa Efek Indonesia pada akhir periode observasi.

2. Perusahaan yang terdaftar secara berturut-turut di Bursa Efek Indonesia selama periode observasi.

3. Perusahaan yang memiliki laporan keuangan lengkap selama periode observasi 
4. Perusahaan memiliki data keuangan yang sesuai dengan variabel-variabel yang akan diuji yaitu, debt to equity ratio, fixed asset to total asset dan asset growth.

5. Perusahaan yang memiliki data bernilai negative

Berdasarkan kriteria atau penilaian tersebut, diperoleh sampel akhir yang berjumlah 19 perusahaan sesuai tabel berikut.

\section{Tabel 2}

Purposive Sampling

\begin{tabular}{clc}
\hline No & \multicolumn{1}{c}{ Kriteria } & Jumlah \\
\hline 1 & $\begin{array}{l}\text { Perusahaan yang terdaftar di Bursa Efek Indonesia } \\
\text { pada akhir periode observasi. }\end{array}$ & 539 \\
2 & $\begin{array}{l}\text { Perusahaan yang tidak terdaftar secara berturut- } \\
\text { turut di Bursa Efek Indonesia selama periode }\end{array}$ & \\
observasi. & \\
3 & $\begin{array}{l}\text { Perusahaan yang tidak memiliki laporan keuangan } \\
\text { lengkap selama periode observasi }\end{array}$ & $(113)$ \\
4 & $\begin{array}{l}\text { Perusahaan yang tidak memiliki data keuangan } \\
\text { yang sesuai dengan variabel-variabel yang akan }\end{array}$ & \\
& diuji yaitu, Debt to Equity Ratio, FATA dan \\
& $\begin{array}{l}\text { Percentage in Total Asset. } \\
\text { Perusahaan yang memiliki data bernilai Negatif }\end{array}$ & \\
& Sampel Akhir & $(87)$ \\
& Jumlah Observasi & 19 \\
\hline
\end{tabular}

Adapun perusahaan yang menjadi sampel tersebut ada pada tabel berikut:

Tabel 3

Daftar Perusahaan Sampel

\begin{tabular}{llc}
\hline NO & \multicolumn{1}{c}{ EMITEN } & KODE \\
\hline 1 & Bisi Internasional, Tbk & BISI \\
2 & PP London Sumatera Indonesia, Tbk & LSIP \\
3 & Salim Ivomas Pratama & SIMP \\
4 & Surya Toto Indonesia, Tbk & TOTO \\
5 & Delta Djakarta, Tbk & DLTA \\
6 & Indofood CBP Sukses Makmur, Tbk & ICBP \\
7 & Mayora Indah, Tbk & MYOR \\
8 & Ultrajaya Milk Industry \& Trading Co, Tbk & ULTJ \\
9 & Darya Varia Laboratoria, Tbk & DVLA \\
10 & Kalbe Farma, Tbk & KLBF \\
11 & Mandom Indonesia, Tbk & TCID \\
12 & Martina Berto, Tbk & MBTO \\
13 & Duta Anggada Realty, Tbk & DART
\end{tabular}


14 Intiland Development, Tbk DILD

15 Lippo Karawaci, Tbk LPKR

16 Tigaraksa Satria, Tbk TGKA

17 Tunas Ridean, Tbk TURI

18 Fast Food Indonesia, Tbk FAST

19 Mas Murni Indonesia, Tbk MAMI

\section{Definisi Operasional Variabel}

Terdapat 2 macam variabel dalam penelitian ini, yaitu variabel dependen dan independen. Variabel dependen dalam penelitian ini adalah Leverage sebagai Y. sedangkan Tangibility sebagai $\mathrm{X}_{1}$ dan Tingkat Pertumbuhan sebagai $\mathrm{X}_{2}$ merupakan variabel independen.

Tabel 4

Definisi Operasional Variabel Penelitian

\begin{tabular}{|c|c|c|}
\hline Variabel & Definisi & Pengukuran \\
\hline $\begin{array}{l}\text { Leverage } \\
\text { (Y) }\end{array}$ & $\begin{array}{l}\text { Debt to Equity Ratio } \\
\text { merupakan perbandingan } \\
\text { antara rasio utang } \\
\text { terhadap modal. }\end{array}$ & $\begin{array}{c}\text { Debt to Equity Ratio } \\
\text { Total Debt } \\
\text { Total Equity }\end{array}$ \\
\hline $\begin{array}{l}\text { Tangibility } \\
\left(\mathrm{X}_{1}\right)\end{array}$ & $\begin{array}{l}\text { Tangibility } \\
\text { merupakan rasio aktiva } \\
\text { tetap terhadap total } \\
\text { aktiva. }\end{array}$ & $\begin{array}{c}\text { FATA } \\
\frac{\text { Fixed Assets }}{\text { Total Assets }}\end{array}$ \\
\hline \multirow{2}{*}{$\begin{array}{c}\text { Tingkat } \\
\text { Pertumbuhan } \\
\left(\mathrm{X}_{2}\right)\end{array}$} & \multirow{2}{*}{$\begin{array}{l}\text { Pertumbuhan dalam } \\
\text { penelitian ini } \\
\text { menggunakan persentase } \\
\text { perubahan pada total } \\
\text { aktiva }(\mathrm{t} 1) \text { terhadap tahun } \\
\text { sekarang }(\mathrm{t})\end{array}$} & $\begin{array}{l}\quad \text { Asset Growth } \\
\text { total asset } t-\text { total asset } t-1\end{array}$ \\
\hline & & total assets \\
\hline
\end{tabular}

\section{Teknik Analisis Data}

Penelitian ini berbentuk pengujian hipotesis yang dimaksudkan untuk menguji pengaruh variabel tangibility dan tingkat pertumbuhan terhadap variabel leverage. Bentuk data yang digunakan dalam penelitian ini berupa data panel. Data panel merupakan gabungan antara data cross section dan time series. Data diambil dari 19 perusahaan sampel yang merupakan data time series dan unit cross section dari periode 2013-2017.

Dalam penelitian ini digunakan metode analisis statistik deskriptif dan regresi data panel dengan bantuan Aplikasi Eviews. Untuk mengetahui tingkat signifikansi dari masing-masing koefisien regresi variabel independen terhadap variabel dependen maka digunakan uji $t$ dan uji f. Persamaan regresi data panel yang digunakan dalam penelitian ini adalah : 


\section{LEVit $=\alpha+\beta_{1}$ TAN $_{\mathrm{it}}+\beta_{2}$ GROW $_{\mathrm{it}}+\mathrm{e}$}

Dimana $\mathrm{LEV}_{\text {it }}$ merupakan leverage perusahaan pada waktu $\mathrm{t} ; \alpha$ merupakan konstanta $; \beta_{1}, \beta_{2}$ merupakan koefisien regresi ; TAN $\mathrm{it}_{\mathrm{it}}$ merupakan tangibility pada waktu $\mathrm{t}$; $\mathrm{GROW}_{\text {it }}$ merupakan tingkat pertumbuhan pada waktu $\mathrm{t}$ ; dan e merupakan error atau toleransi kesalahana.

Pada analisi regresi data panel digunakan 3 macam pendekatan atau model, yaitu common effect, fixed effext dan random effect (Yusra, 2017). Penentuan model terbaik yang digunakan dilakukan dengan melakukan 2 tahap pengujian, yaitu; 1) Chow Test, dilakukan untuk menguji model terbaik yang digunakan antara common effect dengan fixed effect, 2) Hausman Test, dilakukan untuk menentukan model terbaik yang akan digunakan antara fixed effect dengan random effect.

Model regresi yang terbaik tidak boleh menghasilkan estimasi linear yang bias. Model data panel memiliki masalah umum yaitu terjadinya gejala heteroskedastisitas dan autokorelasi karena penggunaan 2 gabungan data yaitu cross section dan time series. Oleh karena itu terlebih dahulu dilakukan uji asumsi klasik. Namun karena dalam penelitian ini menggunakan fixed effect sebagai model regresi data panel, maka uji asumsi klasik tidak relevan jika dilakukan. Karena fixed effect dapat mengatasi masalah autokorelasi runtut waktu (time series) serta korelasi antar observasi (cross section).

\section{HASIL DAN PEMBAHASAN}

Uji Statistik Deskriptif

Uji statistik deskriptif bertujuan untuk memberikan gambaran umum obyek penelitian. Perhitungan statistik deskriptif dalam penelitian ini meliputi nilai minimum, maksimum, mean dan standar deviasi dari masing-masing variabel. Variabel dependen dalam penelitian ini adalah leverage sedangkan tangibility dan tingkat pertumbuhan sebagai variabel independen. Distribusi statistik untuk masing-masing variabel pada penelitian ini terdapat pada tabel dibawah ini:

Tabel 5

Statistik Deskriptif

\begin{tabular}{lcccc}
\hline \multicolumn{1}{c}{ Variabel } & Minimum & Maksimum & Mean & $\begin{array}{c}\text { Std. } \\
\text { Deviasi }\end{array}$ \\
\hline $\begin{array}{l}\text { Leverage (LEV) } \\
\text { Tangibility (TANG) }\end{array}$ & 0.160 & 1.510 & 0.600 & 0.349 \\
Tingkat Pertumbuhan & 0.003 & 0.580 & 0.242 & 0.149 \\
(GROW) & 0.000 & 0.260 & 0.104 & 0.060 \\
\hline
\end{tabular}

Sumber: data diolah, Eviews 8 
Dalam penelitian ini jumlah data akhir yang digunakan sebanyak 95 observasi yang berasal dari kombinasi data cross section sebanyak 19 perusahaan dan time series selama periode 2013-2017. Pada tabel 4 diperlihatkan bahwa tingkat leverage minimum sebesar 0.160, sedangkan maksimum sebesar 1.510. Fluktuasi yang terjadi menjelaskan bahwa struktur modal setiap perusahaan berbeda antara satu dengan lainnya. PT. Mayora Indah, Tbk pada tahun 2014 menjadi perusahaan dengan leverage tertinggi, sedangkan PT. Bisi Internasional, Tbk pada tahun 2013 menjadi perusahaan dengan leverage terendah.

Pada tangibility atau struktur aktiva, PT. Duta Anggada Realty, Tbk menjadi perusahaan dengan tingkat struktur aktiva paling rendah (0.003) pada tahun 2013, sedangkan PT. Mas Murni Indonesia, Tbk menjadi perusahaan dengan struktur aktiva paling tinggi (0.580) pada tahun 2015.

Pada tingkat pertumbuhan, PT. Martina Berto, Tbk menjadi perusahaan dengan tingkat pertumbuhan 0.000 atau tidak ada yang terjadi pada tahun 2013, sedangkan tingkat pertumbuhan paling tinggi yaitu 0.260 terjadi pada PT. Mandom Indonesia, Tbk pada tahun 2014.

\section{Pemilihan Regresi Data Panel}

Dalam regresi data panel, dilakukan pemilihan model terbaik yang akan digunakan antara common effect, fixed effect dan random effect. Persamaan regresi adalah sebagai berikut:

\section{LEVit $=\alpha+\beta_{1}$ TANit $+\beta_{2}$ GROW $i t+e$}

Persamaan ini menggunakan transformasi logaritma pada variabel leverage (dependent) dalam menentukan model terbaik yang akan digunakan. Hasil statistik yang diperoleh dalam pengestimasian model CEM, FEM dan REM adalah sebagai berikut:

\section{Tabel 6}

Tabel Estimasi CEM, FEM dan REM

\begin{tabular}{ccccccc}
\hline \multirow{2}{*}{ Variabel } & \multicolumn{2}{c}{ Common Effect } & \multicolumn{2}{c}{ Fixed Effect } & \multicolumn{2}{c}{ Random Effect } \\
\cline { 2 - 7 } & t-statistik & prob & t-statistik & prob & t-statistik & Prob \\
\cline { 2 - 7 } C & -2.717 & 0.007 & -5.739 & 0.000 & -4.080 & 0.000 \\
TANG & -2.729 & 0.007 & 2.028 & 0.046 & 0.802 & 0.424 \\
GROW & 0.714 & 0.511 & 1.608 & 0.111 & 1.606 & 0.116 \\
\hline
\end{tabular}

Sumber: data diolah, Eviews 8

Tabel 6 menunjukan hasil estimasi masing-masing model memiliki nilai signifikansi yang berbeda-beda. Maka dari itu dilakukan uji lanjut Chow Test untuk menentukan model terbaik yang akan digunakan antara common effect dan fixed effect. Pada penelitian ini tidak dilakukan uji lanjut Hausman Test karena hasil estimasi pada random effect tidak memenuhi syarat untuk dilakukan uji lanjut tersebut. Adapun hasil uji chow seperti pada tabel dibawah ini:

Tabel 7

Chow Test 


\begin{tabular}{lrrr} 
Effects Test & Statistic & d.f. & Prob. \\
\hline \hline Cross-section F & 61.816550 & $(18,74)$ & 0.0000 \\
Cross-section Chi-square & 263.612152 & 18 & 0.0000 \\
\hline \hline
\end{tabular}

Sumber: data diolah, Eviews 8

Berdasarkan tabel diatas diketahui nilai prob pada Cross-section Chi-square lebih kecil daripada alpha $(\alpha)(0.00<0.05)$. Maka H0 ditolak. Artinya fixed effect lebih baik digunakan daripada common effect.

\section{Uji Asumsi Klasik} dibawah ini:

Hasil uji normalitas dengan uji statistik Jarque-Berra dapat diketahui pada tabel

Tabel 8

Hasil Uji Normalitas Tahap I

\section{Jarque-Berra} 27.486

\section{Probability}

$\mathbf{0 . 0 0 0}$

Sumber: data diolah, Eviews 8

Dari tabel 8 diatas, didapatkan hasil uji Jarque-Berra yang memiliki nilai sebesar 27.486 dengan probability 0.000 . Karena nilai probability lebih kecil dari alpha $(0.000<0.05)$ maka dapat dikatakan bahwa residual dalam model penelitian ini tidak berdistribusi normal. Maka dari itu dilakukan transformasi data dengan menggunakan logaritma pada variabel terikat. Setelah ditransformasikan didapatkan hasil seperti gambar dibawah ini:

Tabel 9

Hasil Uji Normalitas Tahap II

\begin{tabular}{cc}
\hline Jarque-Berra & Probability \\
5.410 & 0.066 \\
\hline
\end{tabular}

Sumber: data diolah, Eviews 8

Berdasarkan tabel 9 diatas, didapatkan hasil uji Jarque-Berra mempunyai nilai sebesar 5.410 dengan probability 0.066 . Karena nilai probability lebih besar dari alpha $(0.066>0.05)$ maka dapat dikatakan bahwa residual dalam model penelitian ini telah berdistribusi normal.

\section{Analisis Regresi Data Panel}

Dalam penelitian ini teknik analisi data digunakan untuk mengolah sampel yang sudah diperoleh, membuktikan hipotesis yang telah dibuat dan membahas hasil pengujian hipotesis.

Tabel 10

Hasil Estimasi Regresi Data Panel

\begin{tabular}{ccccc}
\hline Variabel & Coefficient & Std. Error & $t$-Statistic & Prob. \\
\hline
\end{tabular}




\begin{tabular}{ccccc}
\hline C & -1.168 & 0.203 & -5.739 & 0.000 \\
TANG & 1.637 & 0.807 & 2.028 & 0.046 \\
GROW & 0.669 & 0.416 & 1.608 & 0.111 \\
\hline
\end{tabular}

Sumber: data diolah, Eviews 8

Angka pada persamaan regresi data panel didapatkan dari nilai coefficient variabel. Persamaan regresi data panel fixed effect model adalah sebagai berikut:

\section{LEV = -1.1687 + 1.6379 TANGit + 0.6696 AGit}

Berdasarkan pada model regresi diatas, dapat di interpretasikan nilai-nilai tersebut. Dimana Konstanta bernilai -1.168 yang berarti, jika diasumsikan variabel bebas bernilai 0 (tidak ada), maka leverage bernilai konstan sebesar 1.16 .

Koefisien tangibility (TANG) bernilai 1.637 yang berarti setiap peningkatan variabel tangibility (yang diproksi dengan fixed asset to total asset) sebanyak 1 satuan berarti akan meningkatkan variabel leverage sebanyak 1.637 serta beranggapan variabel lain dalam bentuk konstan. Koefisien tingkat pertumbuhan $(G R O W)$ bernilai 0.669 yang berarti setiap peningkatan variabel tingkat pertumbuhan (yang diproksi dengan FATA) sebanyak 1 satuan berarti akan meningkatkan variabel leverage sebanyak 0.669 serta beranggapan variabel lain dalam bentuk konstan.

\section{Hasil Pengujian Hipotesis}

Menurut (Yusra, Hadya, Fernandes, 2017) dalam penelitiannya menyebutkan dasar penarikan kesimpulan untuk hipotesis dilakukan dengan membandingkan t-hitung dengan t-tabel pada tingkat signifikansi 5\%. Apabila thitung besar dari t-tabel (thitung $>$ ttabel) berarti terdapat perbedaan yang signifikan, dalam arti kata nilai Beta $(\beta)$ mampu mengurangi risiko (bisa diprediksi). Sebaliknya, apabila t-hitung kecil dari t-tabel (thitung $<$ ttabel) berarti tidak terdapat perbedaan yang signifikan, dalam arti kata nilai Beta $(\beta)$ tidak mampu mengurangi risiko (tidak bisa diprediksi).

Pada tabel 10 untuk variabel tangibility menunjukkan nilai $\mathrm{T}_{\text {hitung }}$ lebih besar dari $\mathrm{T}_{\text {tabel }}(2.02>1.98)$ atau probability lebih kecil dari alpha $(0,04<0,05)$ maka $\mathrm{H}_{0}$ ditolak dan $\mathrm{Ha}$ diterima. Untuk variabel tingkat pertumbuhan menunjukan nilai $\mathrm{T}_{\text {hitung }}$ lebih kecil dari $\mathrm{T}_{\text {tabel }}(1.608<1.985)$ atau probability lebih besar dari alpha $(0.1119>0,05)$ maka Ha ditolak dan $\mathrm{H}_{0}$ diterima. Maka disimpulkan bahwa tangibility berpengaruh positif dan signifikan terhadap leverage perusahaan. Sedangkan tingkat pertumbuhan tidak berpengaruh signifikan terhadap leverage perusahaan.

\section{PEMBAHASAN}

Pengaruh Tangibility terhadap Leverage 
Berdasarkan pengujian yang telah dilakukan, dapat disimpulkan bahwa Hipotesis pertama yang menyatakan tangibility berpengaruh positif dan signifikan terhadap struktur modal dapat diterima. Artinya semua perusahaan yang menjadi sampel menggunakan aktiva untuk jaminan hutang.

Dengan demikian hasil ini sesuai dengan trade off theory, dimana struktur aktiva memiliki pengaruh positif terhadap struktur modal. Dimana dengan adanya beban bunga hutang maka tingkat penghasilan yang terkena pajak akan berkurang dan memungkinkan perusahaan meningkatkan nilainya. Semakin besar struktur aktiva yang dimiliki perusahaan maka akan semakin besar pula modal yang akan diberikan kreditur.

Hal ini sesuai dengan penelitian yang sebelumnya dilakukan oleh (Fahmi, 2017) yang menyatakan bahwa besarnya aktiva tetap yang dimiliki perusahaan dapat digunakan sebagai jaminan hutang perusahaan. Cahyani, (2017) dalam penelitiannya menyatakan semakin besar aset yang dimiliki oleh perusahaan, maka semakin besar pinjaman yang diperoleh oleh perusahaan atas jaminan yang diberikan kepada kreditur. Semakin besar tangibility assets yang dimiliki oleh perusahaan, maka semakin besar pinjaman yang dapat diperoleh oleh perusahaan atas jaminan yang diberikan kepada kreditur (Kadek et al., 2012).

\section{Pengaruh Tingkat Pertumbuhan terhadap Leverage}

Berdasarkan hasil penelitian diperoleh bahwa hipotesis kedua ditolak karena tidak memenuhi syarat yang telah ditetapkan. Artinya semua perusahaan yang menjadi sampel dengan tingkat pertumbuhan tertentu tidak menggunakan hutang dalam kegiatan operasionalnya.

Secara tersirat perusahaan yang memiliki tingkat pertumbuhan tinggi tetap menggunakan dana internal daripada harus menggunakan hutang untuk biaya modal kerja karena dipenuhi dengan ketidakpastian dan resiko yang tinggi. Dalam hubunganya dengan leverage, perusahaan dengan tingkat pertumbuhan yang tinggi lebih memilih menggunakan dana internal sebagai sumber pembiayaannya agar tidak terjadi agency cost antara investor dengan manajamen perusahaan.

Hal ini didukung oleh penelitian (Asandimitra, 2014) yang menyatakan perusahaan akan menghindari penggunaan hutang, sebab dikhawatirkan perusahaan tidak bisa mengembalikan hutang-hutang tersebut karena penggunaan hutang hanya akan menimbulkan risiko. Perusahaan yang mempunyai tingkat pertumbuhan yang potensial tinggi akan cenderung menghasilkan arus kas yang lebih besar sehingga perusahaan tersebut pada akhirnya akan lebih mengandalkan pendanaan internal (Sutejo, 2013).

\section{SIMPULAN}

Hasil dari penelitian pengaruh Tangibility dan Tingkat Pertumbuhan terhadap Leverage Perusahaan dapat disimpulkan bahwa Pertama, Tangibility berpengaruh positif dan signifikan terhadap Leverage perusahaan pada 
perusahaan yang terdaftar di BEI selama periode 2013-2017. Artinya, jika perusahaan memiliki struktur aktiva yang tinggi atau kuat, maka perusahaan dapat dengan mudah mendapatkan pinjaman dana eksternal dengan menjaminkan aktiva tersebut. Kedua, Tingkat Pertumbuhan berpengaruh negatif dan signifikan terhadap Leverage pada perusahaan yang terdaftar di BEI selama periode 2013-2017. Artinya, perusahaan dengan tingkat pertumbuhan tertentu tiap tahunnya tidak menggunakan hutang untuk membiayai kegiatan operasional.

\section{UCAPAN TERIMAKASIH}

Penyusunan proposal ini tidak lepas dari bimbingan, bantuan dan dukungan sangat berarti dari berbagai pihak. Maka dalam kesempatan ini, penulis ingin menyampaikan ungkapan terima kasih yang sebesar - besarnya kepada :

1. Ketua STIE “KBP” Padang, Bapak Febryandhie Ananda, SE, M.Si

2. Ketua Prodi Manajemen, Ibuk Febsri Susanti, SEI, MM

3. Ibu Lidya Martha, SE, MM selaku Pembimbing Akademik yang telah memberikan arahan dan nasehat kepada penulis.

4. Bapak Irdha Yusra, SE, M.Sc selaku Dosen Pembimbing yang telah memberikan bimbingan kepada penulis serta meluangkan banyak waktu untuk memberikan saran dalam penyusuanan skripsi ini sehingga skripsi ini dapat diselesaikan dengan baik.

5. Serta kepada teman-teman seperjuangan penulis yang terus memberikan masukan dalam proses penulisan skripsi ini.

\section{DAFTAR PUSTAKA}

Yusra, I., Hadya, R., Fernandes, J., Ekonomi, F., \& Ekasakti, U. (2017). Likuiditas, Financial Leverage, Dan Prediktabilitas Beta: Pendekatan, 2(1), 81-91.

Hadya, R., Begawati, N., \& Yusra, I. (2017). 3) 1 2. Analisis Efektivitas Pengendalian Biaya, Perputaran Modal Kerja, Dan Rentabilitas Ekonomi Menggunakan Regresi Data Panel, 01(03), 153-166.

Kuncoro, M. (2011). Metode Kuantitatif Teori Dan Aplikasi Untuk Bisnis \& Ekonomi (Keempat). Yogyakarta: Upp Stim Ykpn.

Maryanti, E., \& Sidoarjo, U. M. (2016). Analisis Profitabilitas , Pertumbuhan Perusahaan, Pertumbuhan Perusahaan Sektor Industri Barang Konsumsi Yang Terdaftar Di Bursa Efek Indonesia ( Studi Empiris Pada Perusahaan Manufaktur Yang Terdaftar Di Bursa Efek Indonesia Tahun Pendahuluan Kajian Pus, 1(2014), 143-151.

Suharli, M. (2006). Studi Empiris Mengenai Pengaruh Profitabilitas,Leverage, Dan Harga Saham Terhadap Jumlah Dividen Tunai (Studi Pada Perusahaan Yang Terdaftar Di Bursa Efek Jakarta Periode 2002-2003). Jurnal Manajemen, Akuntansi Dan Sistem Informasi, 6(2), 243-257. 
Supriyanto, E. K. O., \& Falikhatun. (2008). Pengaruh Tangibility, Pertumbuhan Penjualan Dan Ukuran Perusahaan Terhadap Struktur Keuangan. Jurnal Bisnis Dan Akuntansi, 10(1), 13-22.

Tommy, B., \& Admaja, K. (2010). Pengaruh Profitability, Tangibility, Growth Opportunity, Corporate Tax, Non-Debt Tax Shield, Dan Inflation Rate Terhadap Struktur Modal Pada Perusahaan Manufaktur ( Penelitian Pada Perusahaan Manufaktur Yang Listing Di Bei Tahun 2006 - Program Studi . Wulandari, N. (2017). Analisis Faktor-Faktor Yang Mempengaruhi Inflasi Pada Kota Metropolitan Di Indonesia Dengan Menggunakan Analisis Data Panel, 3(2), 34-42.

Sutejo, B. S., \& Si, M. (2013). Faktor-Faktor Yang Mempengaruhi Struktur Modal Pada Industri, 2(1), 1-11.

Silalahi, U. (2015). Metode Penelitian Sosial Kuantitatif (Keempat). Bandung: Pt Refika Aditama.

Cahyani, N. I. (2017). Pengaruh Profitabilitas, Likuiditas, Size, Kepemilikan Institusional, Dan Tangibility Terhadap Struktur Modal, 6.

Fahmi, L. Z. U. L. (2017). Pengaruh Struktur Aktiva, Ukuran Perusahaan, Dan Likuiditas Terhadap Struktur Modal Luthfillah Zul Fahmi, 6.

Sugiyono. (2017a). Metode Penelitian (26th Ed.). Bandung: Alfabeta.

Sugiyono, P. D. (2017b). Metode Penelitian Bisnis. ( Suryandari Sofia Yustiyani, Ed.) (Edisi 3). Bandung.

Kadek, N., Merta, S., \& Badjra, I. B. (2012). Assets , Ukuran Perusahaan Dan Pajak Terhadap Struktur Modal, 3017-3033.

Sutejo, B. S., Si, M., \& Fakultas, M. (2015). Profitability, Asset Tangibility, Size, Growth, 4(1), 1-14.

Indrajaya, G. (2011). Akurat Jurnal Ilmiah Akuntansi Nomor 06 Tahun Ke-2 September-Desember 2011. 